\title{
SEEDLESS WATERMELON PROPAGATION BY CUTTINGS A. Effect of planting containers, cutting types and IBA on transplants production from cuttings
}

(Received: 13.4. 2014)

\author{
By \\ A. S. A. El-Eslamboly \\ Protected Cultivation Department, Horticulture Research Institute, Agriculture Research Center, Egypt
}

\begin{abstract}
Vegetative propagation is widely used to multiply some horticultural crops. Cuttings are an important method of vegetative propagation. The present study was conducted to propagate seedless watermelon by cuttings and study some factors affecting success of the watermelon cuttings propagation. This technique depends on taking the cuttings from mother plants planted under optimal conditions. Seedless cv. Yellow Buttercup (QV 766) $F_{1}$ (yellow flesh) and SSX $7402 \mathrm{~F}_{1}$ hybrid (red flesh) were used in this study. Two types of cuttings were used; the first type was cuttings from terminal growing point of the main stem and lateral branches with 10 to15 cm in length, 0.4 to $0.6 \mathrm{~cm}$ in diameter and the second type was cuttings included one node, bud and leaf. Two periods of cuttings were taken from these mother plants, at 45 and 75days from transplanting. The cuttings were treated with 3 concentrations of IBA, viz., 0,100 and $200 \mathrm{ppm}$ to promote the adventitious root formation. The first and second cuttings were planted in two types of containers, viz., speedling trays and pots $(8 \mathrm{~cm})$, The study was conducted in factorial experiments in randomized complete block design with three replicates during two successive seasons 2010/2011 and 2011/2012 at a nursery in Badrashein City, Giza Governorate, Egypt.

The results showed no significant differences between both types of containers in all the characteristics in both seasons. IBA concentrations exhibited a significant positive effect on the survival percentage and roots number and length. Cuttings included one node gave a higher survival percentage of cuttings than the terminal cuttings. The same results were obtained for the number and length of roots in the first and second seasons in both hybrids under study. The bilateral and triple interactions among container types, IBA concentrations and cutting types did not show any significant effect. IBA and types of cuttings individually showed significant effects on the cuttings success as a survival percentage, roots formation and number and length of roots. The interaction between IBA and cutting types gave significant effect on the survival percentage only.
\end{abstract}

Key words: cuttings, IBA, propagation, seedless watermelon, triploid.

\section{INTRODUCTION}

Watermelon is an economically important vegetable crop of tropical and temperate parts of the world. Watermelon is appreciated by consumers for its texture, sweetness and flavour of the flesh. It is a good source of vitamins (C and A) and minerals such as potassium, iron and calcium. Watermelon also contains a high amount of lycopene, a carotenoid molecule which, over recent years, has gained considerable interest in diets with respect to its potential as an antioxidant (Fraser and Bramley, 2004). Watermelon has a long history of cultivation in Africa and the Middle East and has been planted in the Nile Valley since the second millennium BC (Zohary et al., 2012). Seedless watermelon did not spread on a commercial scale in Egypt in spite of its sweet taste and lack of hard seeds. The growing costs of seedless watermelon are very expensive because of its very high seed price; seeds do not germinate well and have heterogeneous germination and growth.

Triploid watermelons $(2 n=3 x=33)$ or seedless watermelon are referred to as seedless, though they are not truly seedless, but rather have undeveloped seeds that are soft and edible. These rudimentary small seeds are consumed along with the flesh, just as immature seeds that are eaten in cucumber. The triploid or seedless watermelon was first obtained and described in Japan by crossing female tetraploid and male 
diploid plants (Kihara, 1951). The resulting triploid plants are sterile and do not produce viable seeds. Triploids are developed by creating tetraploid plants by doubling the chromosome number and crossing them with diploid watermelon (Andrus et al., 1971). Tetraploid seeds can be germinated immediately upon harvest and their ploidy is confirmed using different methods. The seed stock of confirmed tetraploids is expanded by repeated selfpollination. Because tetraploids exhibit reduced fertility (Lower and Johnson, 1969). First generation tetraploids may produce only 5-20 seeds per fruit and limited fruit production per plant (maximum of 3-4 fruits per plant with seeds). As many as 10 years may be required to produce the quantity of seed needed to satisfy the commercial demand for new triploid seeds (Compton et al., 2004). In addition, the production of triploid watermelon is more expensive than that of $F_{1}$ hybrids (as much as 510 times) because of the high cost of the seeds, the establishment of the crop from transplants and the necessary presence of a pollinator variety planted with the triploid variety (flowers of triploid plants lack sufficient viable pollen to induce normal fruit set). An adequate bee population is also essential to ensure sufficient pollen transfer. Development of seedless hybrids was discussed in the following stages: 1) choice of diploid lines, 2) production of tetraploid plants, 3) tetraploid line development, and 4) hybrid production and testing (Wehner 2007). Vegetative propagation is widely used to multiply some of horticultural crops. Cutting is an important method of vegetative propagation. Cuttings involve the production of plants from plant parts. They offer a method for propagation of valuable plants such as triploid seedless hybrids for confrontation of the increased demand for seedless cultivars.

Growth regulators, cutting type and condition of the stock plant (mother plants) are very important factors in success the cuttings propagation, while the optimal temperatures for propagation vary enormously between species. Most temperate species require temperatures between $21^{\circ} \mathrm{C}$ and $27^{\circ} \mathrm{C}$ with night temperatures of about $15^{\circ} \mathrm{C}$ for rooting of cuttings (Hartmann et al. 2002). Dawson and King (1994) noted that high root zone temperature relative to air temperature improved rooting percentages of Australian plants, minimal rooting occurring at root zone temperatures of less than $26^{\circ} \mathrm{C}$ at an air temperature of $20^{\circ} \mathrm{C}$. The formation of adventitious roots is an essential step in vegetative propagation and therefore if cuttings do not form roots, losses occur (De Klerk et al., 1999). The discovery of auxins as plant growth regulators in the 1930s and their ability to stimulate adventitious rooting in stem cuttings marked a major milestone in the modern history of plant propagation (Blythe et al., 2007).

Clark et al. (1999) recorded that applying the auxin (indole-3-butyric acid (IBA)) increased adventitious root formation on vegetative stem cuttings of the wild-type plants. Researchers developed new rooting treatments, examining the effects of plant growth regulators (Haissig and Davis, 1994) by a short exposure to a solution with a high auxin concentration or by dipping in rooting powder (auxin with talc).

Mason (2004) reported that IBA is most widely used as a rooting hormone. Cutting is frequently treated with hormones which encourage root development. Treating different plant cuttings by dipping in IBA at 500 to 1000 ppm for few seconds promote adventitious root formation, root number and root length (Ellyard 1981). The application of IBA alone increased root fresh weight especially with the lowest concentration of IBA. IBA is used for rooting in commercial operations (Kenney et al., 1969). Auxin enters cuttings mostly via the cut surface. The successful formation of adventitious roots is an obligatory phase of vegetative propagation in many woody plants; this being related to the presence of auxin (McClelland et al., 1990). IAA was the first used to stimulate rooting of cutting (Cooper 1935) and soon after, IBA, was discovered and was considered even more effective (Zimmerman and Wilcoxon 1935). Nowadays IBA is used commercially to root microcuttings and is more efficient than IAA (Epstein and Ludwig-Müller 1993).

El-Abd (1997) explained that, all IBA treatments were effective in increasing the number, length and fresh weight of adventitious roots in cucumber cuttings as compared with the control. IBA increased ethylene production comparing with Mepiquat Chloride (MC) treatments which reduced ethylene production but enhanced root elongation.

Stem cuttings of Epipremnum aureum treated with IAA + IBA at $300 \mathrm{ppm}$ were proved significantly effective for percentage rooting and more number of leaves (Sharma, 2013). Use of vegetative stem cuttings for the propagation of plants has been found very effective in the number of plants like Ficus carica and Nerium 
indicum (Nambison et al., 1977). Jatropha curcas and $J$. gossypifolia cuttings treated with $300 \mathrm{ppm}$ of auxins and combinations of IAA+IBA, proved significantly effective for percentage rooting (Gaikwad, 2011).

The aim of this study was to develop new pattern of cutting techniques for seedless watermelon plant propagation to minimize the amounts of imported watermelon seeds in general and seedless watermelon in particular and study the effect of type of cutting, type of container and IBA in addition to the interaction between all of them on the cutting success.

\section{MATERIAL AND METHODS}

These experiments were conducted during 2010/2011 and 2011/2012 using two seedless watermelon hybrids. These experiments included 12 treatments, viz., two types of cuttings (cuttings from terminal growing point of the main stem and lateral branches $10-15 \mathrm{~cm}$ in length and 0.4-0.6 cm in diameter and cuttings included one node, bud and leaf) three concentrations of IBA $(0,100,200 \mathrm{ppm})$ for treating cuttings before planting and two planting containers namely speedling trays and pots no.8. These cuttings were taken from mother plants after 45 and 75 days from planting.

\subsection{Plant material}

\subsubsection{Watermelon hybrids}

Two seedless watermelon (C. lanatus) hybrids, viz., Buttercup (QV 766) $F_{1}$ (yellow flesh) and SSX $7402 \mathrm{~F}_{1}$ (red flesh)) from Sakata Seed Company, Japan were used as a mother plants in the present study.

\subsection{Nursery of cuttings}

Seedless watermelon seeds were sown in the greenhouse in Badrashein city on 7 October in 2010 in the first season and 12 October in 2011 in the second season in foam speedling trays with 84 cells filled with a mixture of peat-moss, vermiculite and berlite at the ratio of 1:1:1 (v/v). Three hundred grams of ammonium sulphate, $400 \mathrm{~g}$ calcium superphosphate, $150 \mathrm{~g}$ potassium sulphate, $50 \mathrm{ml}$. nutrient solution and $50 \mathrm{~g}$ of a fungicide were added for each $50 \mathrm{~kg}$ of the peatmoss. Sixty seedlings from each seedless watermelon hybrid were transplanted on 12 November 2010 and 18 November 2011 in plastic house in Badrashein city as mother plants to obtain cuttings in both seasons.

Mother plants (stock plants) were treated with the conventional agricultural practices, i.e., irrigation, fertilization, pests and diseases management as recommended by the Ministry of
Agriculture, Egypt. For producing good watermelon vegetative growth, all female flowers and fruits were removed. The first cuttings were collected after 45 days from planting then the second cuttings were collected after 30 days from the previous collection. Four shoot tip cuttings and 12 cuttings including one node were collected at 45 days from planting. On the other hand, after 75 days 8 cuttings including shoot tip and 30 one node cuttings were taken from each cultivar. Suitable branches chosen for cutting were obtained from the shoot tip, upper, middle and bottom nodal segments of all primary or secondary branches.

All shoot tip and one node cuttings collected at each cutting date chosen were divided into three groups, the first group was treated with $200 \mathrm{ppm}$ IBA, the second group was treated with $100 \mathrm{ppm}$ IBA. Treatment was conducted by dipping these cuttings in IBA solution for 10 seconds followed by immersing the bases of the cuttings in Mepiquat Chloride solution at the concentration of $100 \mathrm{ppm}$. The third group was immersed in distilled water for 10 seconds. The treated and untreated cuttings were planted in speedling trays 84 cells or pots no. 8 filled with previously mentioned culture mixture.

Speedling trays and pots were transferred immediately after planting into the shaded plastic low tunnel for healing and hardening as well as root formation from the node region. A polyethylene sheet was laid on the floor of low tunnels and covered with a shallow layer of water. Speedling trays were placed on bricks to support the plants above the water layer. The plastic tunnel was closed to achieve a temperature of $25-32{ }^{\circ} \mathrm{C}$ and $>85 \%$ RH humidity for seven days. Watermelon plants formed from cuttings were moved out of the tunnel and placed in a screen house for ten days.

\subsection{Experimental design and statistical analysis}

This study was conducted in factorial experiment in a randomized complete block design with three replicates. Each cutting time and each hybrid was considered as a separate experiment. Data were statistically analyzed using analyses of variance by the technique of analysis of variance ANOVA, with the Stat Soft Statistical Package MSTATC software program (Michigan State University, East Lansing, MI, USA). Probabilities of significance among treatments and means were compared with least significant difference $\operatorname{LSD}(\mathrm{P} \leq 0.05)$ according to Gomez and Gomez (1984). 


\subsection{Studied characteristics}

2.4.1. Number of cuttings collected each time 2.4.2. Survival percentage

Survival percentage was recorded after 12 days from planting by counting the succeeded transplants and divided them by the planted number of cuttings.

2.4.3. Number of roots formed on 10 cuttings after 12 days from planting.

2.4.4. Length of roots formed on 10 cuttings after 12 days from planting.

\section{RESULTS AND DISCUSSION}

Data in Table (1) shows that, the number of cuttings included shoot tip and cuttings include one node that were taken from the mother plants at all times under this study.

Mother plants were remained in good status until 105 days. Some plants (Buttercup (QV766 $\left.\mathrm{F}_{1}\right)$ and $\left(\mathrm{SSX} 7402 \mathrm{~F}_{1}\right)$ were lost thereafter.

Data in Table (1) also illustrated that the total number of cuttings from mother plants (20 plants) in both cultivars as average of both seasons at 45 and 75 days was 1080 in each cultivar. At 75 days, the mother plants in both hybrids gave 760 cuttings, while at 45 days mother plants gave 320 cuttings (Buttercup $\left(\mathrm{QV} 766 \mathrm{~F}_{1}\right)$ and $\left(\mathrm{SSX} 7402 \mathrm{~F}_{1}\right)$.
Data in the same Tables indicated that treating watermelon cuttings with IBA had a significant effect on the survival percentage, the number of roots and average root length in 'Buttercup (QV 766) $\mathrm{F}_{1}$ ' and 'SSX $7402 \mathrm{~F}_{1}$ that were recorded in both cuttings after 45 and 75 days from planting in the first and second seasons. The concentration of $200 \mathrm{ppm}$ showed higher values of survival percentage, the number of roots and root length compared to the cuttings treated with $100 \mathrm{ppm}$ IBA and the control plants. IBA concentrations significantly improved the percentage of survival, the number of roots and root length in 'Buttercup (QV 766) $\mathrm{F}_{1}$ ' and 'SSX $7402 F_{1}$. These results may be due to the enhancement of IBA for root formation on cuttings. The present results agree with the finding of Srivastava (2002 )who reported that auxins (both natural and synthetic) have been known to stimulate the formation of lateral and adventitious roots. Overvoorde et al. (2010) reported that auxins such as IBA play an important role in the initiation of roots on cuttings.

In roots, the most well characterized auxinassociated phenotypes are the dose-dependent increase in the length of epidermal-derived root hairs, the bimodal effect of auxin concentration

Table (1): Total number of cuttings obtained from the mother plants in both hybrids in both seasons (average of 2 years).

\begin{tabular}{|c|c|c|c|c|c|c|c|c|c|c|}
\hline \multirow{3}{*}{$\begin{array}{l}\text { Days from } \\
\text { transplanting }\end{array}$} & \multicolumn{10}{|c|}{2010 and 2011} \\
\hline & \multicolumn{2}{|c|}{$\begin{array}{l}\text { No. of mother } \\
\text { plants }\end{array}$} & \multirow{2}{*}{$\begin{array}{c}\text { No. of } \\
\text { shoot } \\
\text { tips } \\
\text { taken } \\
\text { from } \\
\text { each } \\
\text { plant }\end{array}$} & \multicolumn{2}{|c|}{$\begin{array}{l}\text { Total number } \\
\text { of shoot tips }\end{array}$} & \multirow{2}{*}{$\begin{array}{l}\text { No. of } \\
\text { one } \\
\text { node } \\
\text { taken } \\
\text { from } \\
\text { each } \\
\text { plant }\end{array}$} & \multicolumn{2}{|c|}{$\begin{array}{l}\text { Total number of } \\
\text { one node cuttings }\end{array}$} & \multicolumn{2}{|c|}{$\begin{array}{c}\text { Total number of } \\
\text { cuttings taken from } \\
20 \text { plant }\end{array}$} \\
\hline & $\begin{array}{c}\text { Buttercup } \\
\text { QV 766 } \\
\text { F }_{1} \\
\end{array}$ & $\begin{array}{c}\text { SSX } \\
7402 \\
F_{1} \\
\end{array}$ & & \begin{tabular}{|} 
Buttercup \\
QV 766 \\
F $_{1}$ \\
\end{tabular} & $\begin{array}{c}\text { SSX } \\
7402 \\
F_{1} \\
\end{array}$ & & Buttercup & $\begin{array}{c}\text { SSX } \\
7402 \\
\text { F }_{1}\end{array}$ & $\begin{array}{c}\text { Buttercup } \\
\text { QV 766 } \\
\text { F }_{1}\end{array}$ & $\begin{array}{c}\text { SSX } \\
7402 \\
F_{1} \\
\end{array}$ \\
\hline 45 & 20 & 20 & 4 & 80 & 80 & 12 & 240 & 240 & 320 & 320 \\
\hline 75 & 20 & 20 & 8 & 160 & 160 & 30 & 600 & 600 & 760 & 760 \\
\hline $\begin{array}{c}\text { Total No. of cuttings } \\
\text { after } 75 \text { days }\end{array}$ & & & & 240 & 240 & & 840 & 840 & 1080 & 1080 \\
\hline
\end{tabular}

\subsection{Effect of single factors}

Data in Tables (2 and 3) showed insignificant differences between the two types of containers.

It is worth mentioning that speedling trays and pots No. 8 did not have any effect on the survival percentage or the plant cuttings that were developed to plants and roots formed. No remarkable effect was shown on the number of root formed and the average roots length that was formed on cuttings of both hybrids in the first and second cutting days, i.e., 45 and 75 days after planting. on primary root length, the dose-dependent increase in the number of lateral root primordia, and the response to gravity (Ishida et al., 2008). This relatively high rooting percentage $(61 \%)$ and low percentage of cutting death (18\%) may be due to the fact that auxin may have enhanced cutting survival as well as stimulating root growth. In particular, IBA is important to improve rooting percentage in English holly (Weiser and Blaney, 1960).

The container type had no effect on all the characteristics under this study. Applying IBA 
increased the number of roots per cutting and root length in both cultivars (Tables 2 and 3).

Type of cutting had significant effect on survival percentage, the number of roots and root length. One node cuttings showed a significant increment in the survival percentage, the number of roots and average root length than the terminal cutting or cutting include shoot tip which showed lower values in survival percentage, number of roots and average root length. The highest survival percentage was obtained from cuttings which included one node $(97 \%)$ whereas the lowest survival percentage was obtained from cuttings of shoot tip (68.86\%).

In this regard, Rieckermann, et al. (1999) reported that terminal plant cuttings required a long time for root formation. In contrast, subterminal cuttings produce more shoot and root growth. The present results are in agreement with several previous reports which revealed that cutting types can be used in propagation such as hardwood, softwood, semi hard wood, herbaceous,leaf, and root cuttings(Corbett, 1902).

Single node cuttings were used to maximize the number of cuttings per stock plant. Rooting was known to be often associated with nodes and making the bottom cut just below a node was common recommendation (Rieckermann et al., 1999).

Table (2): Effect of container type, IBA concentrations and cutting types on the survival percentage, the number of roots and root length of cuttings from mother plants after 45 days on two seedless watermelon hybrids in two seasons.

\begin{tabular}{|c|c|c|c|c|c|c|c|c|c|c|c|c|}
\hline & \multicolumn{4}{|c|}{ Survival \% } & \multicolumn{4}{|c|}{ Number of roots } & \multicolumn{4}{|c|}{ Root length } \\
\hline & \multicolumn{2}{|c|}{$\begin{array}{c}\text { Buttercup }(Q V \\
766) F_{1}\end{array}$} & \multicolumn{2}{|c|}{ SSX $7402 F_{1}$} & \multicolumn{2}{|c|}{$\begin{array}{c}\text { Buttercup }(Q V \\
766) F_{1}\end{array}$} & \multicolumn{2}{|c|}{$\begin{array}{c}\text { SSX } 7402 \\
F_{1} \\
\end{array}$} & \multicolumn{2}{|c|}{$\begin{array}{c}\text { Buttercup }(Q V \\
766) F_{1}\end{array}$} & \multicolumn{2}{|c|}{ SSX $740 F_{1}$} \\
\hline & 2011 & 2012 & 2011 & 2012 & 2011 & 2012 & 2011 & 2012 & 2011 & 2012 & 2011 & 2012 \\
\hline Trays & 80.50 & 81.44 & 81.15 & 80.43 & 7.88 & 7.65 & 7.68 & 7.61 & 6.51 & 7.72 & 67 & 7.89 \\
\hline Pots & 81.64 & 81.88 & 81.76 & 80.87 & 7.85 & 7.86 & 7.69 & 7.66 & 6.60 & 7.76 & 8.51 & 7.98 \\
\hline LSD at 0.05 & NS & NS & NS & NS & NS & NS & NS & NS & NS & NS & NS & NS \\
\hline \multicolumn{13}{|l|}{ IBA ppm } \\
\hline $\mathbf{0}$ & 8.57 & 8.65 & 78.80 & & 7.15 & 7.24 & 6.96 & 6.99 & 5.9 & 7. & 8.01 & 7.48 \\
\hline 10 & 81.28 & 2.41 & 81.99 & 9 & 7.83 & 7.83 & 7.89 & 7.68 & 6. & 7.8 & 67 & 7.85 \\
\hline 21 & 83.36 & 83.93 & 83.56 & 82.80 & 8.61 & 8.19 & 8.20 & 8.24 & 7.1 & 8.2 & 9.10 & 8.47 \\
\hline LSD at 0.05 & 1.69 & 1.29 & 1.89 & 1.87 & 0.55 & 0.35 & 0.65 & 0.39 & 0.3 & 0.45 & 0.36 & 0.24 \\
\hline \multicolumn{13}{|c|}{ Cutting Types } \\
\hline Shoot tip & 65.43 & 66.56 & 66.59 & 65.17 & 6.26 & 6.04 & 6.35 & 6.04 & 4.75 & 6.12 & 6.62 & 6.22 \\
\hline One nodes & 96.71 & 96.76 & 96.31 & 96.13 & 9.47 & 9.47 & 9.02 & 9.23 & 8.36 & 9.36 & 10.57 & 9.64 \\
\hline LSD at 0.05 & 15.34 & 18.91 & 14.85 & 18.64 & 2.00 & 1.96 & 1.54 & 2.87 & 2.96 & 2.12 & 2.31 & 1.65 \\
\hline
\end{tabular}

Table (3): Effect of container type, IBA concentrations and cutting types on the survival percentage, the number of roots and root length of cuttings from mother plants after 75 days on two seedless watermelon hybrids in two seasons.

\begin{tabular}{|c|c|c|c|c|c|c|c|c|c|c|c|c|}
\hline & \multicolumn{4}{|c|}{ Survival \% } & \multicolumn{4}{|c|}{ Number of roots } & \multicolumn{4}{|c|}{ Root length } \\
\hline & \multicolumn{2}{|c|}{$\begin{array}{c}\text { Buttercup }(Q V \\
766) F_{1}\end{array}$} & \multicolumn{2}{|c|}{ SSX $7402 F_{1}$} & \multicolumn{2}{|c|}{$\begin{array}{l}\text { Buttercup } \\
\left(\text { QV 766) F } F_{1}\right.\end{array}$} & \multicolumn{2}{|c|}{ SSX $7402 F_{1}$} & \multicolumn{2}{|c|}{$\begin{array}{c}\text { Buttercup }(Q V \\
\text { 766) } F_{1}\end{array}$} & \multicolumn{2}{|c|}{ SSX $7402 F_{1}$} \\
\hline & 2011 & 2012 & 2011 & 2012 & 2011 & 2012 & 2011 & 2012 & 2011 & 2012 & 2011 & 2012 \\
\hline Trays & 81.95 & 81.41 & 81.51 & 82.17 & 7.09 & 7.18 & 7.69 & 8.17 & 7.27 & 8.11 & 7.78 & 8.02 \\
\hline Pots & 81.90 & 81.82 & 82.07 & 83.36 & 7.08 & 7.5 & 7.55 & 8.2 & 7.32 & 8.15 & 7.80 & 8.09 \\
\hline LSD at 0.05 & NS & NS & NS & NS & NS & $\lambda$ & NS & $\mathrm{N}$ & $N$ & NS & NS & NS \\
\hline \multicolumn{13}{|l|}{ IBA ppm } \\
\hline $\mathbf{0}$ & 78.86 & 79.43 & 79.81 & 79.59 & 6.50 & 6.85 & 7.10 & 7.64 & 6.69 & 7.62 & 7.06 & 7.44 \\
\hline 100 & 82.92 & 81.64 & 82.07 & 83.10 & 7.16 & 7.41 & 7.69 & 8.23 & 7.23 & 8.24 & 7.99 & 8.05 \\
\hline 200 & 83.99 & 83.77 & 83.50 & 85.61 & 7.58 & 7.85 & 8.07 & 8.71 & 7.97 & 8.53 & 8.32 & 8.68 \\
\hline LSD at 0.05 & 1.542 & 1.131 & 1.360 & 2.522 & 0.356 & 0.321 & 0.278 & 0.465 & 0.500 & 0.356 & 0.350 & 0.368 \\
\hline \multicolumn{13}{|c|}{ Cutting Types } \\
\hline Shoot tip & 66.84 & 66.67 & 67.02 & 68.86 & \begin{tabular}{|l|}
4.88 \\
\end{tabular} & 5.4 & 5.87 & 6.79 & 5.3 & 6.60 & 6.44 & 6.54 \\
\hline One nodes & 97.00 & 96.57 & 96.56 & 96.67 & 9.28 & 9.26 & 9.38 & 9.60 & 9.27 & 9.66 & 9.15 & 9.57 \\
\hline LSD at 0.05 & 14.32 & 12.65 & 17.36 & 15.39 & 2.25 & 2.47 & 1.96 & 1.89 & 2.12 & 2.00 & 1.85 & 2.19 \\
\hline
\end{tabular}




\subsection{Effect of the bilateral interaction}

With regard to the effect of bilateral interactions, data in Tables (4 and 5) illustrated that there were no significant effects for all bilateral interactions on survival percentage, number of roots and average root length in both seedless watermelon hybrids in the first and second cutting times in both seasons.

\subsection{Effect of the triple interaction}

As for the effect of the triple interaction, data in Tables (6 and 7) revealed that, survival percentage, average root length and the number of roots on the cuttings were not significantly affected by the interaction between container types and both IBA concentrations and cutting types in both seedless watermelon hybrids in the first and second cuttings in both seasons.

Table (4): Effect of bilateral interaction between container type with IBA concentrations, container type with cutting type and IBA concentrations with cutting types on the survival percentage, the number of roots and root length on cuttings from mother plants after $\mathbf{4 5}$ days on two seedless watermelon hybrids in two seasons.

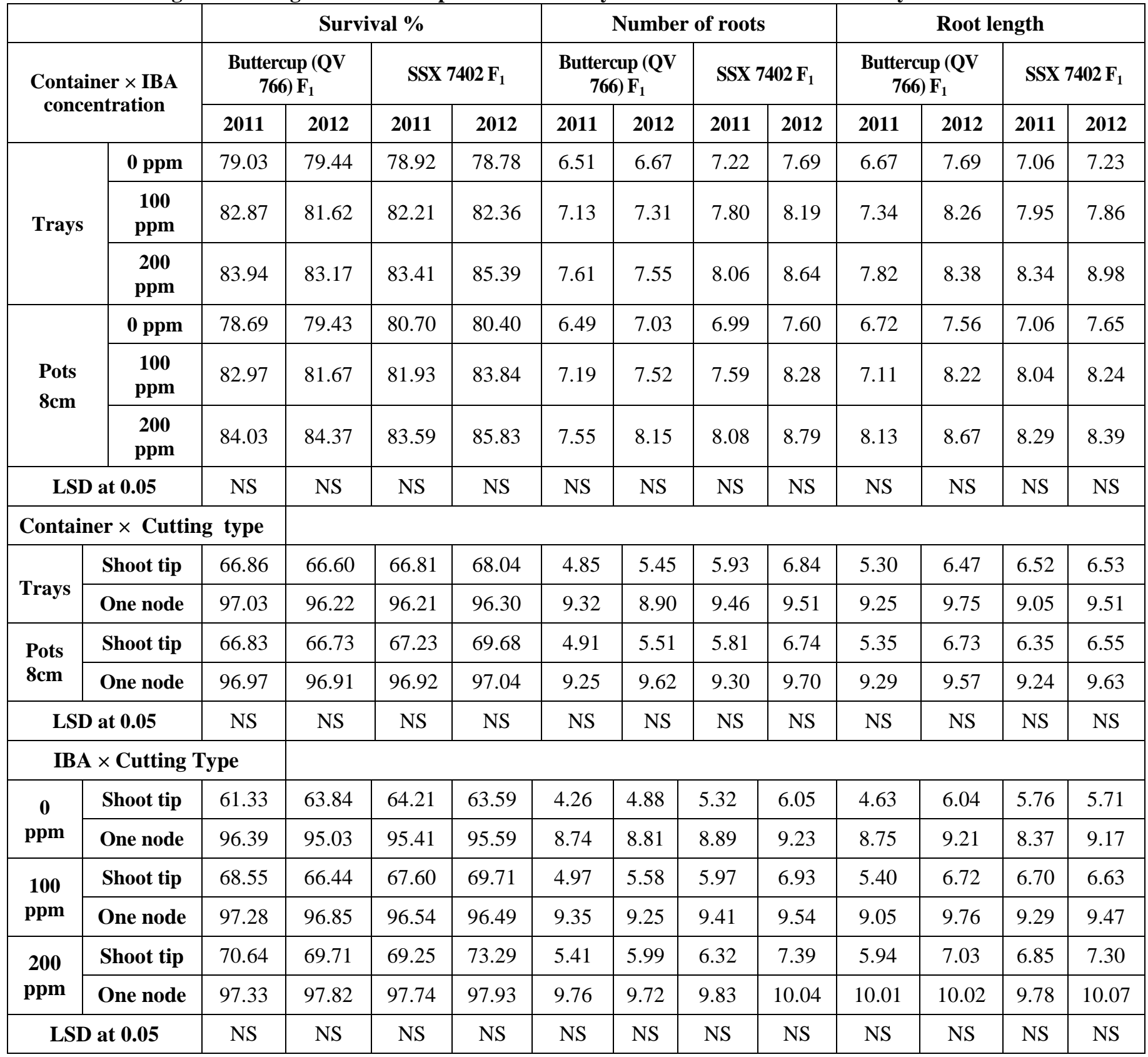


Table (5): Effect of bilateral interaction between container type with IBA concentrations, container types with cutting types and IBA concentrations with cutting types on the survival percentage, the number of roots and root length on cuttings from mother plants after 75 days on two seedless watermelon hybrids in two seasons.

\begin{tabular}{|c|c|c|c|c|c|c|c|c|c|c|c|c|c|}
\hline \multirow{3}{*}{\multicolumn{2}{|c|}{\begin{tabular}{|c|} 
Containers $\times$ IBA \\
concentrations
\end{tabular}}} & \multicolumn{4}{|c|}{ Survival \% } & \multicolumn{4}{|c|}{ Number of roots } & \multicolumn{4}{|c|}{ Root length } \\
\hline & & \multicolumn{2}{|c|}{$\begin{array}{c}\text { Buttercup }(Q V \\
766) F_{1}\end{array}$} & \multicolumn{2}{|c|}{ SSX $7402 \mathrm{~F}_{1}$} & \multicolumn{2}{|c|}{$\begin{array}{c}\text { Buttercup }(Q V \\
766) F_{1}\end{array}$} & \multicolumn{2}{|c|}{ SSX 7402 F $_{1}$} & \multicolumn{2}{|c|}{$\begin{array}{c}\text { Buttercup } \\
\left(\text { QV 766) } F_{1}\right.\end{array}$} & \multicolumn{2}{|c|}{ SSX $7402 F_{1}$} \\
\hline & & 2011 & 2012 & 2011 & 2012 & 2011 & 2012 & 2011 & 2012 & 2011 & 2012 & 2011 & 2012 \\
\hline \multirow{3}{*}{ Trays } & O ppm & 78.21 & 78.36 & 78.73 & 78.22 & 7.19 & 7.17 & 6.96 & 6.91 & 5.87 & 7.14 & 8.14 & 7.51 \\
\hline & 100 ppm & 80.51 & 82.22 & 81.67 & 81.10 & 7.92 & 7.79 & 7.85 & 7.64 & 6.62 & 7.85 & 8.79 & 7.89 \\
\hline & $200 \mathrm{ppm}$ & 82.79 & 83.74 & 83.04 & 81.98 & 8.53 & 7.97 & 8.23 & 8.29 & 7.05 & 8.18 & 9.09 & 8.26 \\
\hline \multirow{3}{*}{$\begin{array}{l}\text { Pots } \\
8 \mathrm{~cm}\end{array}$} & 0 ppm & 78.92 & 78.93 & 78.88 & 77.91 & 7.11 & 7.30 & 6.97 & 7.07 & 6.06 & 7.11 & 7.88 & 7.45 \\
\hline & $100 \mathrm{ppm}$ & 82.05 & 82.60 & 82.31 & 81.08 & 7.74 & 7.87 & 7.93 & 7.71 & 6.41 & 7.79 & 8.55 & 7.81 \\
\hline & $200 \mathrm{ppm}$ & 83.94 & 84.12 & 84.08 & 83.62 & 8.69 & 8.41 & 8.18 & 8.19 & 7.33 & 8.36 & 9.11 & 8.67 \\
\hline \multicolumn{2}{|c|}{ LSD at 0.05} & $\mathrm{NS}$ & $\mathrm{NS}$ & $\mathrm{NS}$ & $\mathrm{NS}$ & NS & NS & $\mathrm{NS}$ & $\mathrm{NS}$ & $\mathrm{NS}$ & NS & $\mathrm{NS}$ & $\mathrm{NS}$ \\
\hline \multicolumn{14}{|c|}{ Containers $x$ Cutting Types } \\
\hline \multirow{2}{*}{ Trays } & Shoot tip & 64.63 & 66.58 & 66.19 & 64.71 & 6.20 & 5.96 & 6.43 & 6.05 & 4.68 & 6.10 & 6.68 & 6.27 \\
\hline & One node & 96.37 & 96.30 & 96.10 & 96.15 & 9.56 & 9.33 & 8.92 & 9.17 & 8.34 & 9.35 & 10.66 & 9.50 \\
\hline \multirow{2}{*}{$\begin{array}{l}\text { Pots } \\
\text { 8cm }\end{array}$} & Shoot tip & 66.23 & 66.54 & 67.0 & 65.64 & 6.32 & 6.12 & 6.26 & 6.02 & 4.82 & 6.14 & 6.55 & 6.17 \\
\hline & One node & 97.04 & 97.22 & 96.52 & 96.10 & 9.37 & 9.60 & 9.12 & 9.29 & 8.38 & 9.37 & 10.48 & 9.78 \\
\hline \multicolumn{2}{|c|}{ LSD at 0.05} & $\mathrm{NS}$ & NS & NS & NS & NS & NS & $\mathrm{NS}$ & NS & NS & NS & NS & NS \\
\hline \multicolumn{14}{|c|}{ IBA $\times$ Cutting Types } \\
\hline \multirow{2}{*}{ O ppm } & Shoot tip & 61.80 & 62.04 & 62.70 & 61.61 & 5.26 & 5.46 & 5.68 & 5.31 & 4.04 & 5.47 & 6.00 & 5.84 \\
\hline & One node & 95.31 & 95.25 & 94.91 & 94.51 & 9.05 & 9.02 & 8.25 & 8.67 & 7.86 & 8.78 & 10.02 & 9.11 \\
\hline \multirow{2}{*}{$\begin{array}{c}100 \\
\text { ppm }\end{array}$} & Shoot tip & 65.71 & 67.81 & 67.37 & 65.87 & 6.27 & 6.15 & 6.61 & 6.18 & 4.87 & 6.27 & 6.73 & 6.11 \\
\hline & One node & 96.84 & 97.01 & 96.61 & 96.31 & 9.39 & 9.51 & 9.16 & 9.18 & 8.16 & 9.37 & 10.61 & 9.60 \\
\hline \multirow{2}{*}{$\begin{array}{c}200 \\
\text { ppm }\end{array}$} & Shoot tip & 68.76 & 69.83 & 69.70 & 68.03 & 7.25 & 6.51 & 6.76 & 6.63 & 5.35 & 6.61 & 7.12 & 6.71 \\
\hline & One node & 97.97 & 98.03 & 97.42 & 97.56 & 9.97 & 9.87 & 9.65 & 9.85 & 9.03 & 9.94 & 11.08 & 10.22 \\
\hline \multicolumn{2}{|c|}{ LSD at 0.05} & NS & NS & NS & NS & NS & NS & $\mathrm{NS}$ & $\mathrm{NS}$ & NS & NS & $\mathrm{NS}$ & NS \\
\hline
\end{tabular}

Table (6): Effect of triple interaction among container type, IBA concentrations and cutting types on the survival percentage, the number of roots and root length on cuttings from mother plants after 45 days on two seedless watermelon hybrids in two seasons.

\begin{tabular}{|c|c|c|c|c|c|c|c|c|c|c|c|c|c|c|}
\hline & \multicolumn{4}{|c|}{ Survival \% } & \multicolumn{4}{|c|}{ Number of roots } & \multicolumn{4}{|c|}{ Root length } \\
\hline & & & \multicolumn{12}{|c|}{ Cultivars } \\
\hline & \multirow{2}{*}{ IBA } & \multirow[b]{2}{*}{$\begin{array}{c}\text { Cutting } \\
\text { types }\end{array}$} & \multicolumn{2}{|c|}{$\begin{array}{c}\text { Buttercup }(Q V \\
766) F_{1}\end{array}$} & \multicolumn{2}{|c|}{ SSX $7402 F_{1}$} & \multicolumn{2}{|c|}{$\begin{array}{l}\text { Buttercup } \\
\text { (QV 766) F }\end{array}$} & \multicolumn{2}{|c|}{ SSX 7402 F $_{1}$} & \multicolumn{2}{|c|}{$\begin{array}{c}\text { Buttercup }(Q V \\
\text { 766) } F_{1} \\
\end{array}$} & \multicolumn{2}{|c|}{ SSX $7402 F_{1}$} \\
\hline & & & 2011 & 2012 & 2011 & 2012 & 2011 & 2012 & 2011 & 2012 & 2011 & 2012 & 2011 & 2012 \\
\hline \multirow{6}{*}{ 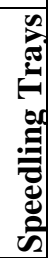 } & \multirow{2}{*}{$\begin{array}{c}\mathbf{0} \\
\text { ppm } \\
\end{array}$} & Shoot tip & 61.58 & 63.93 & 63.04 & 62.61 & 4.27 & 4.76 & 5.32 & 6.01 & 4.72 & 6.02 & 5.75 & 5.55 \\
\hline & & One node & 96.49 & 94.95 & 94.79 & 94.95 & 8.76 & 8.57 & 9.12 & 9.37 & 8.61 & 9.35 & 8.37 & 8.91 \\
\hline & \multirow{2}{*}{\begin{tabular}{|c|}
100 \\
Ppm \\
\end{tabular}} & Shoot tip & 68.34 & 66.89 & 67.84 & 68.51 & 4.84 & 5.67 & 6.17 & 7.01 & 5.29 & 6.64 & 6.81 & 6.27 \\
\hline & & One node & 97.39 & 96.36 & 96.58 & 96.20 & 9.43 & 8.95 & 9.42 & 9.37 & 9.39 & 9.89 & 9.09 & 9.45 \\
\hline & \multirow{2}{*}{$\begin{array}{c}200 \\
\text { Ppm }\end{array}$} & Shoot tip & 70.65 & 68.98 & 69.55 & 73.01 & 5.45 & 5.92 & 6.29 & 7.50 & 5.88 & 6.75 & 7.00 & 7.79 \\
\hline & & One node & 97.23 & 97.35 & 97.26 & 97.77 & 9.77 & 9.19 & 9.83 & 9.79 & 9.76 & 10.01 & 9.68 & 10.17 \\
\hline \multirow{6}{*}{$\begin{array}{l}\infty \\
0 \\
\dot{0} \\
0 \\
0 \\
0\end{array}$} & \multirow{2}{*}{$\begin{array}{c}\mathbf{0} \\
\text { Ppm }\end{array}$} & Shoot tip & 61.08 & 63.76 & 65.37 & 64.57 & 4.25 & 5.00 & 5.33 & 6.09 & 4.54 & 6.05 & 5.76 & 5.87 \\
\hline & & One node & 96.29 & 95.11 & 96.02 & 96.23 & 8.72 & 9.05 & 8.65 & 9.10 & 8.90 & 9.07 & 8.37 & 9.43 \\
\hline & \multirow{2}{*}{$\begin{array}{c}100 \\
\text { Ppm }\end{array}$} & Shoot tip & 68.76 & 65.99 & 67.35 & 70.90 & 5.11 & 5.49 & 5.76 & 6.85 & 5.50 & 6.81 & 6.59 & 6.99 \\
\hline & & One node & 97.18 & 97.30 & 96.51 & 96.79 & 9.28 & 9.54 & 9.41 & 9.71 & 8.71 & 9.63 & 9.48 & 9.48 \\
\hline & \multirow{2}{*}{$\begin{array}{c}200 \\
\text { Ppm }\end{array}$} & Shoot tip & 70.63 & 70.44 & 68.95 & 73.56 & 5.36 & 6.05 & 6.34 & 7.28 & 6.00 & 7.31 & 6.70 & 6.80 \\
\hline & & One node & 97.43 & 98.29 & 98.22 & 98.09 & 9.74 & 10.25 & 9.83 & 10.29 & 10.27 & 10.02 & 9.88 & 9.98 \\
\hline & \multicolumn{2}{|c|}{ LSD at 0.05} & NS & NS & NS & $\mathrm{NS}$ & NS & NS & NS & $\mathrm{NS}$ & $\mathrm{NS}$ & $\mathrm{NS}$ & $\mathrm{NS}$ & NS \\
\hline
\end{tabular}


Table (7): Effect of triple interaction among container types, IBA concentrations and cutting types on the survival percentage, the number of roots and root length on cuttings from mother plants after 75 days on two seedless watermelon hybrids in two seasons.

\begin{tabular}{|c|c|c|c|c|c|c|c|c|c|c|c|c|c|c|}
\hline & \multicolumn{4}{|c|}{ Survival \% } & \multicolumn{4}{|c|}{ Number of roots } & \multicolumn{4}{|c|}{ Root length } \\
\hline & & & \multicolumn{12}{|c|}{ Cultivars } \\
\hline & \multirow{2}{*}{ IBA } & \multirow[b]{2}{*}{$\begin{array}{c}\text { Cutting } \\
\text { types }\end{array}$} & \multicolumn{2}{|c|}{$\begin{array}{c}\text { Buttercup }(Q V \\
\text { 766) } F_{1} \\
\end{array}$} & \multicolumn{2}{|c|}{ SSX $7402 F_{1}$} & \multicolumn{2}{|c|}{$\begin{array}{c}\text { Buttercup }(Q V \\
\text { 766) } F_{1} \\
\end{array}$} & \multicolumn{2}{|c|}{ SSX $7402 F_{1}$} & \multicolumn{2}{|c|}{$\begin{array}{c}\text { Buttercup } \\
(\text { QV 766) F } 1\end{array}$} & \multicolumn{2}{|c|}{ SSX $7402 F_{1}$} \\
\hline & & & 2011 & 2012 & 2011 & 2012 & 2011 & 2012 & 2011 & 2012 & 2011 & 2012 & 2011 & 2012 \\
\hline \multirow{6}{*}{ 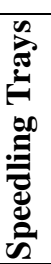 } & \multirow{2}{*}{\begin{tabular}{|c|}
$\mathbf{0}$ \\
$\mathbf{p p m}$
\end{tabular}} & Shoot tip & 61.31 & 61.89 & 62.72 & 61.31 & 5.21 & 5.39 & 5.67 & 5.29 & 3.98 & 5.50 & 5.99 & 5.87 \\
\hline & & One node & 95.12 & 94.83 & 94.74 & 95.13 & 9.17 & 8.97 & 8.25 & 8.54 & 7.77 & 8.78 & 10.28 & 9.15 \\
\hline & \multirow{2}{*}{$\begin{array}{c}100 \\
\text { ppm }\end{array}$} & Shoot tip & 64.52 & 68.05 & 66.61 & 65.53 & 6.19 & 6.15 & 6.72 & 6.06 & 4.77 & 6.25 & 6.96 & 6.29 \\
\hline & & One node & 96.49 & 96.38 & 96.74 & 96.66 & 9.66 & 9.42 & 8.97 & 9.22 & 8.47 & 9.46 & 10.62 & 9.50 \\
\hline & \multirow{2}{*}{\begin{tabular}{|c|}
200 \\
ppm
\end{tabular}} & Shoot tip & 68.07 & 69.78 & 69.26 & 67.28 & 7.19 & 6.34 & 6.90 & 6.82 & 5.30 & 6.54 & 7.09 & 6.67 \\
\hline & & One node & 97.51 & 97.70 & 96.82 & 96.67 & 9.86 & 9.60 & 9.55 & 9.77 & 8.80 & 9.82 & 11.08 & 9.86 \\
\hline \multirow{6}{*}{ 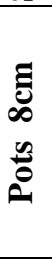 } & \multirow{2}{*}{$\begin{array}{c}\mathbf{0} \\
\text { ppm }\end{array}$} & Shoot tip & 62.33 & 62.19 & 62.69 & 61.92 & 5.31 & 5.53 & 5.68 & 5.33 & 4.09 & 5.45 & 6.01 & 5.82 \\
\hline & & One node & 95.51 & 95.67 & 95.07 & 93.90 & 8.92 & 9.06 & 8.25 & 8.81 & 8.02 & 8.78 & 9.75 & 9.07 \\
\hline & \multirow{2}{*}{$\begin{array}{c}100 \\
\text { ppm }\end{array}$} & Shoot tip & 66.90 & 67.57 & 68.13 & 66.21 & 6.36 & 6.15 & 6.50 & 6.29 & 4.96 & 6.30 & 6.50 & 5.93 \\
\hline & & One node & 97.20 & 97.63 & 96.48 & 95.95 & 9.12 & 9.59 & 9.35 & 9.13 & 7.86 & 9.28 & 10.60 & 9.69 \\
\hline & \multirow{2}{*}{$\begin{array}{c}200 \\
\text { ppm }\end{array}$} & Shoot tip & 69.46 & 69.87 & 70.15 & 68.78 & 7.31 & 6.68 & 6.61 & 6.44 & 5.41 & 6.67 & 7.14 & 6.76 \\
\hline & & One node & 98.42 & 98.37 & 98.02 & 98.46 & 10.08 & 10.14 & 9.75 & 9.94 & 9.26 & 10.06 & 11.08 & 10.58 \\
\hline & \multicolumn{2}{|c|}{ LSD at 0.05} & NS & NS & NS & NS & NS & NS & NS & NS & NS & NS & NS & NS \\
\hline
\end{tabular}

\section{Conclusions}

1. The container type had no effect on the survival percentage, root number and length.

2. Applying IBA increased the number and length of roots per cutting and the percentage of survival plants.

3. Cuttings included one node showed significant increment in the number of roots, root length and survival plants which reached $97 \%$ while the survival percentage of the cuttings destined from shoot tip reached $68.8 \%$.

\section{REFERENCES}

Adelberg J. W., Zhang X. P. and Rhodes B. B. (1997). Micropropagation of Citrullus lanatus (Thunb.) Mastsum. and Nakai (Watermelon). pp 60-76. In: Bajaj, Y. P. S. (Ed.) Biotechnology in Agriculture and Forestry, High-Tech Micropropagation V, Vol. 39, SpringerVerlag, Berlin, Heidelerg, ISBN: 3-54061606-3, $401 \mathrm{p}$.

Andrus C.F., Seshadri V. S. and Grimbal P. C. (1971). Production of seedless watermelons. Technical Bulletin, No. 1425. Agricultural Research Service (ARS), United States Department of Agriculture (USDA), Charleston, South Carolina, 12 p.( Cited after Adelberg et al., 1997).

Blythe E. K., Sibley J.L., Tilt K. M., and Ruter J. M. (2007). Methods of auxin application in cutting propagation: A review of 70 years of scientific discovery and commercial practice. J. Env. Hort., 25(3):166-185.

Clark D.G., Gubrium E.K., Barrett J.E., Nell T.A. and Klee H.J. (1999). Root formation in ethylene-insensitive plants. Plant Physiol., 121: 53-59.

Compton M. E., Gray D. J. and Gab V. P. (2004). Use of tissue culture and biotechnology for the genetic improvement of melon. PCTOC7:231243.

Cooper W.C. (1935). Hormones in relation to root formation on stem cutting. Plant physiol., 10: 789-794.

Corbett L.C. (1902). The propagation of plants. United States Department of Agriculture: Farmers' Bulletin, No. 157, $23 \mathrm{p}$.

Dawson I.A. and King R.W. (1994). Propagation of some woody Australian plants from cutting. Australian J. Exper. Agric., 34: 1225-1231.

De Klerk G. J, Van der Krieken W. and de Jong J. (1999). Review the formation of adventitious roots: New concepts, new possibilities. In Vitro Cell. and Devel. Biol. Plant, 35(3):189-199.

El-Abd M.T.G. (1997). Vegetative propagation of cucumber hybrid 'Cattia'. Egypt j. of Hort., 24 (1): 59-66.

Ellyard R.K. (1981). Effect of auxin combinations on rooting of Persoonia 
chamaepitys and $P$. pinifolia cutting. Combined Proceedings International Plant Propagators' Society, 31: 251-255.

Epstein E. and Ludwig-Müller J. (1993). Indole3-butyric acid in plants: occurrence, synthesis, metabolism and transport. Physiol. Plant., 88 (2):382-389.

Fraser P. D. and Bramley P. M. (2004). The biosynthesis and nutritional uses of carotenoids. Progress in Lipid Research, 43:228-265.

Gaikwad R. S. (2011). Vegetative propagation of Jatropha species by stem cuttings. Curr. Bot., 2(1):39-40.

Gomez K. A. and Gomez A. A. (1984). Statistical Procedures for Agricultural Research. International Rice Research Institute, $2^{\text {nd }}$ Ed. John Wiley and Sons. Inc. New-York, $680 \mathrm{p}$.

Haissig B.E. and Davis T.D. (1994). A historical evaluation of adventitious rooting research to 1993, pp. 275-331. In: Davis TD, Haissig BE (Eds.). Biology of adventitious root formation. Basic Life Sciences, 62, Springer Science, Business Media New-York, USA, ISBN 978-14757-9494-6. 343 p.

Hartmann H.T., Kester D. E., Davies F. T. and Geneve R. L. (2002). Plant Propagation; Principles and Practices. $7^{\text {th }}$ Edition, New Jersey: Regent-Prentice Hall, USA $07458,873 \mathrm{p}$.

Ishida T., Kurata T., Okada K. and Wada T. (2008). A genetic regulatory network in the development of trichomes and root hairs. Annual Review of Plant Biology, 59: 365-386.

Kenney G., Sudi J. and Blackman G.E. (1969). The uptake of growth substances. XIII. Differential uptake of indole-3-acetic acid through the epidermal and cut surfaces of etiolated stem segments. J. Exp. Bot., 20:820-840.

Kihara H. (1951). Triploid watermelon. Proceeding of the American Society for Horticultural Science, 58:217-230.

Lower R. L. and Johnson K. W. (1969). Observations on sterility of induced autotetraploid watermelons. J. Amer. Soc. Hort. Science, 94:367-369

Mason J. (2004). Nursery Management. $2^{\text {nd }}$ Edition. ISBN $\quad 0 \quad 643 \quad 09213 \quad 7$ (NetLibrary eBook). Landlinks Press, Collingwood VIC 3066 Australia, 320 p.
McClelland M.T., Smith M.A.L. and Carothers Z. B. (1990). The effects of in vitro and ex vitro root initiation on subsequent microcutting root quality in three woody plants. PCTOC (Historical Archive), 23:115-123.

Nambison K. M. P., Subhaiah R., Rajsekaran K. and Manivel L. (1977). Effect of age of wood time and growth regulators on rooting of cuttings of $N$. olender. South Indian Hort., 25(4): 151-153.

Overvoorde P., Fukaki H. and Beeckman T. (2010). Auxin control of root development. Cold Spring Harbor Perspectives in Biology, 2(6): 1-16.

Perry F. (1997). Effects of auxin treatment, cutting type and air and root zone temperatures on cutting propagation of eastern species of Conospermum and Persoonia with potential horticultural value. School of Botany, La Trobe University, Report to the Australian Flora Foundation, $24 \mathrm{p}$.

Rieckermann H., Goldfarb B., Cunningham M. and Kellison R. C. (1999). Influence of nitrogen, photoperiod, cutting type, and clone on root and shoot development of rooted stem cuttings of sweet gum. New Forests, 18: 231-244.

Sharma J. (2013). Vegetative propagation of Epipremnum aureum by stem cuttings. Online Int. Interdisciplinary Res. J., 3(5): 111-114.

Srivastava L. M. (2002). Plant Growth and Development Hormones and Environment. Copyrighted material, Elsevier science (USA). ISBN: 0-12660570-x, Academic Press, Library of Congress Control Number: 2001093721, $772 \mathrm{p}$.

Wehner T. C. (2007). Watermelon. pp 380-418. In: Prohens J. and Nuez F. (Eds) Handbook of Plant Breeding; Vegetables I: Asteraceae, Brassicaceae, Chenopodicaceae, and Cucurbitaceae. ISBN: 978-0-387-72291-7, Springer, Library of Congress Control Number: 2007936360, $426 \mathrm{p}$.

Weiser C.J. and Blaney L.T. (1960). The effects of boron on the rooting of English holly cuttings. Proceedings of the American Society of Horticultural Science, 75: 704-710.

Zimmerman P. W. and Wilcoxon F. (1935). 
Several chemical growth substances which cause initiation of roots and other responses in plants. Contributions from Boyce Thompson Institute, 7:209-229.

(Cited after Perry F., 1997)

Zohary D., Hopf M. and Weiss E. (2012).
Domestication of Plants in the Old World The origin and spread of domesticated plants in Southwest Asia, Europe, and the Mediterranean Basin. $4^{\text {th }}$ Edition, ISBN: 9780199549061 Oxford University press, $264 \mathrm{pp}$.

$$
\begin{aligned}
& \text { اكثار البطيخ عديم البذور بواسطة العقل } \\
& \text { أ. تأثثير أوعية الزراعة ونوع العقلة واندول حمض البيوتريك علئي انتاج الثتلات } \\
& \text { احمد عبدالهادي سيد عبد الوهاب الاسلامبولي }
\end{aligned}
$$

قسم بحوث انتاج الخضر تحت ظروف جوية معدلةـ معهد بحوث البساتين - مركز البحوث الزراعية ـ الجيزة- مصر.

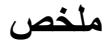

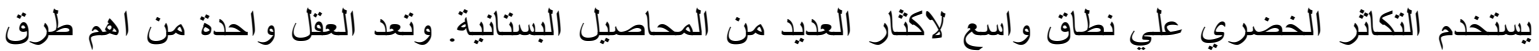

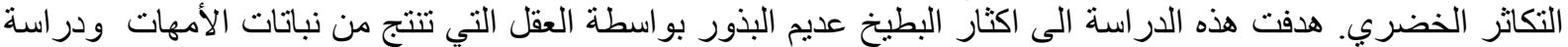

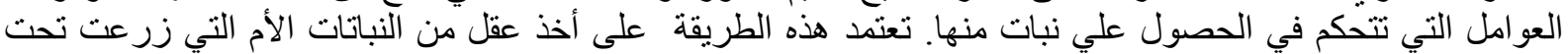
ظروف مثلى في صوبة الامهات.

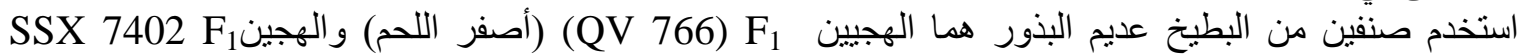

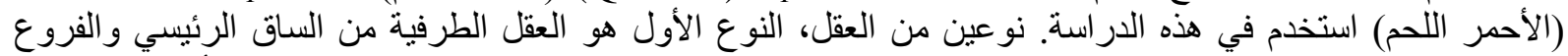

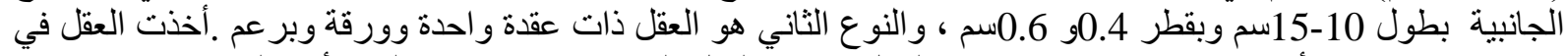

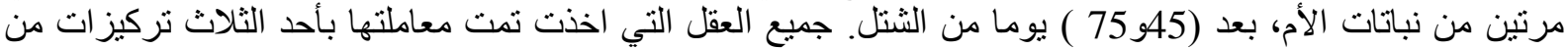

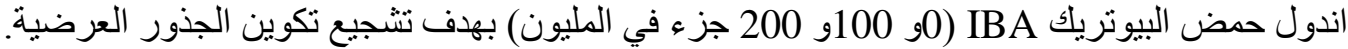

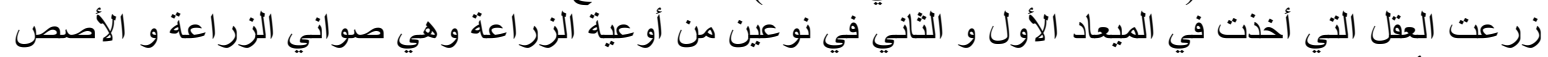

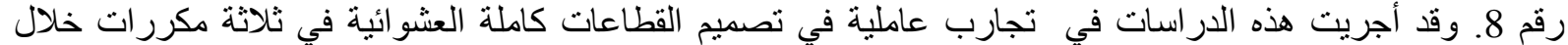

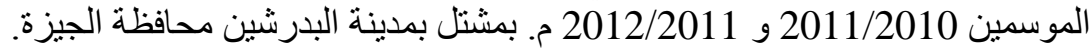

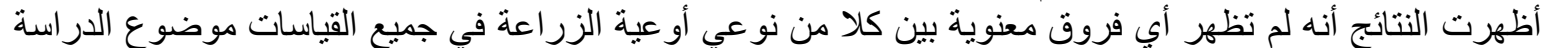

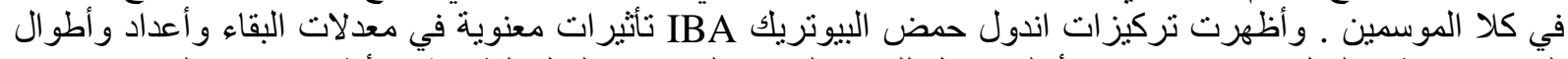

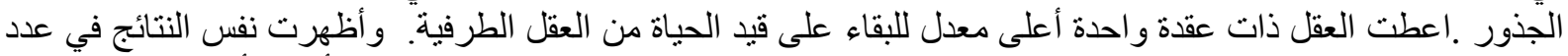

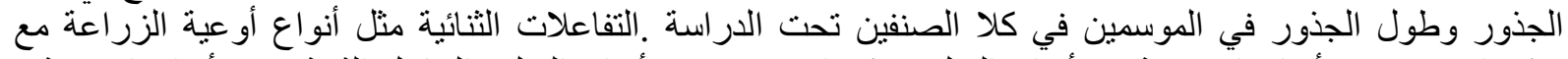

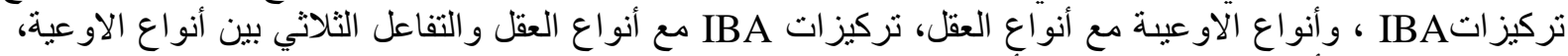

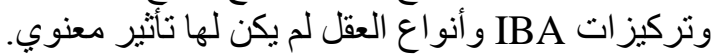

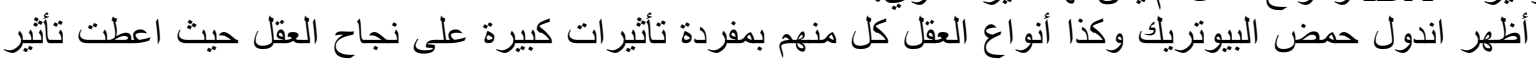

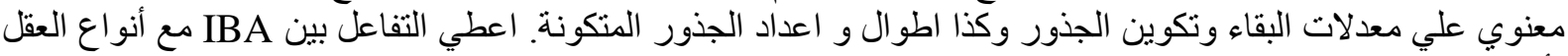
تأثثير ات كبيرة في معدلات البقاء. 